\title{
Color stability evaluation of micro-hybrid composite resins submitted to accelerated artificial aging
}

\author{
- Gisseli Bertozzi Ávila Private practice, Poços de Caldas, MG, Brazil • Sérgio Candido Dias Private practice, Poços de \\ Caldas, MG, Brazil • Mariana Lima da Costa Valente Department of Dental Materials and Prosthesis, School of Dentistry \\ of Ribeirão Preto, University of São Paulo, Ribeirão Preto, SP, Brazil • José Augusto Marcondes Agnelli Department of \\ Materials, Federal University of São Carlos, São Carlos, SP, Brazil • Andréa Cândido dos Reis Department of Dental Materials \\ and Prosthesis, School of Dentistry of Ribeirão Preto, University of São Paulo, Ribeirão Preto, SP, Brazil
}

ABSTRACT | Objective: The aesthetics of dental materials is extremely important for the success of oral rehabilitation. Thus, in the present study we evaluated the color stability and the surface degradation of three micro-hybrid composite resins after accelerated artificial aging process (AAA). Methods: 24 specimens $(\mathrm{n}=8)$ were prepared for each material: Solidex, Artglass and Cesead, dimensions of $\varnothing 15 \mathrm{~mm}$ by $2 \mathrm{~mm}$ in thickness. Samples were subjected to color analysis, before and after AAA, in a spectrophotometer according to the CIE L*a*b* parameters, and a sample of each material was selected for morphological evaluation under scanning electron microscopy (SEM). Data were submitted to one-way ANOVA and Tukey test $(\alpha=0.05)$. Results: Artglass showed higher stability regarding the presence of red and yellow $(\mathrm{p}<0.05)$ when subjected to AAA and fewer of these pigments ( $\mathrm{p}<0.05$ ) when compared to the Cesead and Solidex, which showed the highest luminance stability $(\mathrm{p}<0.05)$. $\Delta \mathrm{E}$ Cesead was the most unstable $(\mathrm{p}<0.05)$. All resins analyzed by SEM showed superficial degradation when submitted to AAA, mainly in resin Cesead. Conclusion: All materials analyzed demonstrate color change and surface degradation and Cesead resin showed the worse results.

DESCRIPTORS | Accelerated Artificial Aging; Color Stability; Composite Resin; Esthetics Dental; Morphological.

RESUMO Avaliação da estabilidade da cor de resinas compostas micro-híbridas submetidas ao envelhecimento artificial acelerado • Objetivo: A estética dos materiais dentários é extremamente importante para o sucesso da reabilitação oral. Assim, no presente estudo, avaliamos a estabilidade de cor e a degradação superficial de três resinas compostas micro híbridas após o processo de envelhecimento artificial acelerado (EAA). Métodos: Foram preparados 24 espécimes $(\mathrm{n}=8)$ para cada material: Solidex, Artglass e Cesead, dimensões de Ø $15 \mathrm{~mm}$ por $2 \mathrm{~mm}$ de espessura. As amostras foram submetidas a análise de cor, antes e depois do EAA, num espectrofotômetro de acordo com os parâmetros CIE L * a * b *, e uma amostra de cada material foi selecionada para avaliação morfológica por microscopia eletrônica de varredura (MEV). Os dados foram submetidos à one-way ANOVA e teste de Tukey $(\alpha=0,05)$. Resultados: A Artglass apresentou maior estabilidade quanto à presença de vermelho e amarelo $(\mathrm{p}<0,05)$ quando submetida ao EAA e menor quantidade destes pigmentos $(\mathrm{p}<0,05)$ quando comparado à Cesead e Solidex, as quais apresentaram maior estabilidade de luminância $(\mathrm{p}<0,05) . \Delta \mathrm{E}$ Cesead foi o mais instável $(\mathrm{p}<0,05)$. Todas as resinas analisadas por MEV apresentaram degradação superficial quando submetidas ao EAA, principalmente na resina Cesead. Conclusão: Todos os materiais analisados demonstram alteração de cor e degradação da superfície, a resina Cesead apresentou os piores resultados.

DESCRITORES | Envelhecimento Artificial Acelerado; Estabilidade de Cor; Resinas Compostas; Estética Dentária; Morfológico.

CORRESPONDING AUTHOR | - Andréa Cândido dos Reis Department of Dental Materials and Prosthesis, School of Dentistry of Ribeirão Preto, University of São Paulo • Av. do Café, $\mathbf{s} / \mathbf{n}^{\circ}$, Monte Alegre Ribeirão Preto, SP, Brazil • 14040-904 Email: andreare73@yahoo.com.br

- Received Aug 29,2015 • Accepted Oct 16, 2015

- Dol http://dx.doi.org/10.11606/issn.2357-8041.clrd.2015.128882 


\section{INTRODUCTION}

Dental materials such as composite resins has enabled dental tissue reconstruction with biofunctional properties, excellent aesthetic potential and acceptable longevity using a minimally invasive approach. ${ }^{1}$ The composites have become the dentists' materials of choice for most restorations, due to their sophisticated aesthetic characteristics in the anterior region and due to their adequate biomechanical strength when used in posterior teeth. ${ }^{2-5}$

Choosing an esthetic restorative material is largely due to its ability to imitate the color of the dental element. ${ }^{6}$ Using it as a model for obtaining the optical characteristics of dentin and enamel is based on the concept of natural stratification, a simple and effective approach to manufacture highly aesthetic direct restorations. However, preparing aesthetically perfect restorations with direct composite resin is still a challenge for clinicians, because of the complexity to reproduce in these materials the optical properties of natural teeth. ${ }^{4}$

Besides color, fundamental to aesthetic harmony, an ideal composite must have adequate physical and mechanical properties to maintain its stability and longevity in the long run.7 There are many factors in the oral environment that can affect the lifespan of these restorations, due to adverse conditions in the oral cavity and the complex oral microflora, such as caries, solubility, fractures, staining, abrasion. Therefore, one of the goals of contemporary dentistry is to develop new solutions to solve such problems. ${ }^{8,9}$

The difficulties presented by conventional resin composites have led the dental industry to develop new materials, such as indirect resins reinforced by fibers, glass polymers, ceromers or laboratory resins. These materials combine high loads of hybrid micro filler particles ranging from 0.4 to $1 \mu \mathrm{m}$, with portions of colloidal silica and multifunctional monomers. This combination gives the resins similar mechanical characteristics to natural teeth, as well as increased hardness, lower solubility, excellent polish, and better discoloration resistance. ${ }^{7}$

The color stability of a composite is not only determined by the material composition, finishing and polishing of the restoration, it can also be affected by exposure time in the oral cavity and by the patient's eating habits. ${ }^{6}$ There are three types of color change reported in the literature: (a) external, due to plaque buildup; (b) surface or subsurface, due to surface degradation or slight penetration and adsorption of dyes within the surface layer of the composites; and (c) inherent, due to the physicochemical reactions on the surface of the resin matrix and in the deeper layers of the material, caused by UV radiation, thermal energy or moisture, the latter usually simulated in vitro studies via artificial accelerated aging. ${ }^{10-12}$ Over the years, studies ${ }^{13,14}$ have examined the effects of type, size and filler particles on the optical properties of composites, and as the aesthetic maintenance of restorations is a critical factor for their longevity, the objective of this investigation was to evaluate three different modified composites (micro-hybrids) for color stability, after being subjected to the accelerated artificial aging (AAA) process and to surface degradation by scanning electron microscopy. The null hypothesis tested was that accelerated artificial aging (AAA) would have no effect on color stability and surface degradation of different modified composites.

\section{MATERIALS AND METHOD}

Twenty-four micro-hybrid composite resins were prepared $(n=8)$ : Artglass (Heraeus Kulzer, South America Ltda. Batch: 020117), Cesead (Kuraray Medical Inc. Batch: 410db) and Solidex (Shofu Dental Corporation. Batch: 060332), for this preparation Teflon matrices with a diameter of 15 $\mathrm{mm}$ and a height of $2 \mathrm{~mm}$ were used.

The matrix was filled with the resin in unique increments and excesses were removed with 26x76 mm glass slide (Perfecta Ind. Com. de 
lâminas de vidro, Ibitinga, Sao Paulo/Brazil), which gave specimens plane and polished surfaces. Subsequently, the set matrix/resin was polymerized in curing oven according to the manufacturer's recommendations for each trademark used in the study, elapsed time of polymerization, the specimens were removed from the matrix for further analysis.

Samples were submitted to color readings using a spectrophotometer (PCB 6807 BYK GARDNER, Geretsried/Germany), and initial color values of the samples were obtained. The observation standard simulated by the equipment followed the CIE $L^{*} a^{*} b^{*}$ system. This system uses three parameters to define color, light, shadow and saturation. Luminosity is the light level and dark object, represented by the $\mathrm{L}^{*}$ value $\left(\mathrm{L}^{*}=100\right.$ for white and $\mathrm{L}^{*}=0$ for bla$\mathrm{ck}$ ), and $\mathrm{a}^{*} \mathrm{~b}^{*}$ parameters (shaded) represent the red $+a^{*}$ and green is $-a^{*}$, yellow if $+b^{*}$ and $-b^{*}$ is blue..$^{10,15}$

After the first reading, the samples were placed in the AAA chamber (Comexim Maturias Primas Ltda, Sao Paulo/Brazil) for non-metal substances C-UV under ultra violet (UV) radiation and condensation in different repeated cycles (successively and automatically). The AAA procedure is performed in a laboratory environment that indicates the behavior of a material under certain conditions and it is widely used for development and control of different properties of materials. ${ }^{16,17}$ In this equipment, the UV-B source was fluorescent light bulbs that emitted concentrated ultraviolet light. Condensation was produced by exposing one surface of a specimen to a heated, saturated mixture of air and water vapor while the reverse side of the specimen was adhered to metal plates with silicone, specifically indicated, under the action of the condensation process at a distance of $50 \mathrm{~mm}$ from the light source. The system was programmed to expose specimens to UV-B at $50^{\circ} \mathrm{C}$ for $4 \mathrm{~h}$, followed by $4 \mathrm{~h}$ of condensation at $50^{\circ} \mathrm{C}$, totaling $191 \mathrm{~h}$ of aging, which is equivalent to 5 years of aging. ${ }^{15}$
After aging, the specimens were subjected to another color reading process by the spectrophotometer. Thus, we obtained measures of color change $(\Delta \mathrm{E})$ before and after artificial accelerated aging, which was automatically calculated by the formula: ${ }^{18} \Delta E^{*}=\left[\left(\Delta L^{*}\right)^{2}+\left(\Delta a^{*}\right)^{2}+\left(\Delta b^{*}\right)^{2}\right]^{1 / 2}$. Values of $\Delta L^{*}$, $\Delta \mathrm{a}^{*}, \Delta \mathrm{b}^{*}$, correspond to the difference of the values $\mathrm{L}^{*}, \mathrm{a}^{*}, \mathrm{~b}^{*}$, respectively, compared to the first color reading (initial). $\Delta \mathrm{E}$ values $\geq 3.3$ are considered clinically unacceptable..$^{12,19,20}$

Morphology of specimens before and after AAA was analyzed by scanning electron microscopy (XL-3o FEG; Philips, Eindhoven/The Netherlands) at an accelerating voltage of $20 \mathrm{kV}$.

Data were submitted to the following statistical tests: normality test (Kolmogorov-Smirnov), parametric test (ANOVA) and multiple comparisons test (Tukey- $\alpha=0.05$ ). The NCSS 2007 (NCSS, Kaysville, UT/USA) software was used in the analyses.

\section{RESULTS}

Table 1 shows the average values for coordinates $L^{*}, a^{*}$ and $b^{*}$, before and after AAA. The Artglass and Cesead resins showed significantly different luminosity averages before and after the AAA, unlike Solidex that showed no statistical difference ( $p>0.05)$. Comparing the overall average, the luminosity measurement of Artglass was significantly higher $(p<0.05)$ when compared with other resins, which showed that Solidex had higher luminosity rates $(p<0.05)$ than Cesead.

The coordinate values of $\mathrm{a}^{*}$ show that the measurement of the amount of red was statistically different $(p<0.05)$ only for Cesead and Solidex resins. Regarding the overall average, the values of $\mathrm{a}^{*}$ for Artglass were significantly lower than those of Cesead and Solidex, which were similar ( $p>0.05$ ).

The amount of yellow for Artglass was similar ( $p>0.05)$ before and after AAA and significantly higher $(p<0.05)$ after AAA for Cesead and Solidex resins. In general, the coordinate $b^{*}$ values of 
Table 1 || Mean and standard deviation (SD) values for coordinates $L$ *, a* and $b$ * before and after accelerated artificial aging (AAA).

\begin{tabular}{c|c|c|c} 
& & Before AAA & After AAA \\
\hline & $L^{*}$ & $78.35(0.91)^{\mathrm{a}}$ & $78.94(0.53)^{\mathrm{b}}$ \\
\hline Artglass & $\mathrm{a}^{*}$ & $2.13(0.17)^{\mathrm{a}}$ & $2.02(0.13)^{\mathrm{a}}$ \\
\hline & $\mathrm{b}^{*}$ & $17.64(0.29)^{\mathrm{a}}$ & $17.04(1.04)^{\mathrm{a}}$ \\
\hline & $\mathrm{L}^{*}$ & $74.92(1.18)^{\mathrm{a}}$ & $73.41(1.04)^{\mathrm{b}}$ \\
\hline & $\mathrm{a}^{*}$ & $4.03(0.29)^{\mathrm{a}}$ & $3.66(0.43)^{\mathrm{b}}$ \\
\hline Cesead & $\mathrm{b}^{*}$ & $20.34(0.72)^{\mathrm{a}}$ & $23.36(1.38)^{\mathrm{b}}$ \\
\hline & $\mathrm{L}^{*}$ & $76.55(0.56)^{\mathrm{a}}$ & $76.56(0.48)^{\mathrm{a}}$ \\
\hline & $\mathrm{a}^{*}$ & $4.05(0.36)^{\mathrm{a}}$ & $3.47(0.38)^{\mathrm{b}}$ \\
\hline & $\mathrm{b}^{*}$ & $21.54(0.92)^{\mathrm{a}}$ & $23.53(0.71)^{\mathrm{b}}$ \\
\hline
\end{tabular}

${ }^{\dagger}$ Equal lowercase letters in the same line indicate statistical similarity $¥ \mathrm{~L}$ *: Luminosity; $a *$ : Coordinate red/green; $b *$ : Coordinate yellow/blue

Table 2 | Comparison of mean $\Delta \mathrm{E}$ and standard deviation (SD) of different resins.

\begin{tabular}{c|c} 
Resin & $\Delta \mathrm{E}(\mathrm{SD})$ \\
\hline Artglass & $1.31(0.90) \mathrm{a}$ \\
\hline Cesead & $3.51(1.04) \mathrm{b}$ \\
\hline Solidex & $2.12(0.06) \mathrm{a}$ \\
\hline
\end{tabular}

${ }^{\dagger}$ Equal lowercase letters in the same column indicate statistical similarity

${ }^{\ddagger} \Delta$ E Color change

the Artglass composite were significantly lower $(p<0.05)$ when compared to the others and in the pre-aging time the measurements of Cesead were lower $(p<0.05)$ when compared to Solidex.

The color stability analysis (Table 2) indicated that only the composite Cesead showed unacceptable color change $(\Delta E \geq 3.3)$. Artglass $(\Delta E=1.31 \pm 0.90)$ and Solidex $(\Delta E=2.12 \pm 0.06)$ resins showed clinically acceptable results.

All resins showed superficial changes after AAA detected by morphological analysis (Figure. 1, 2 and 3).
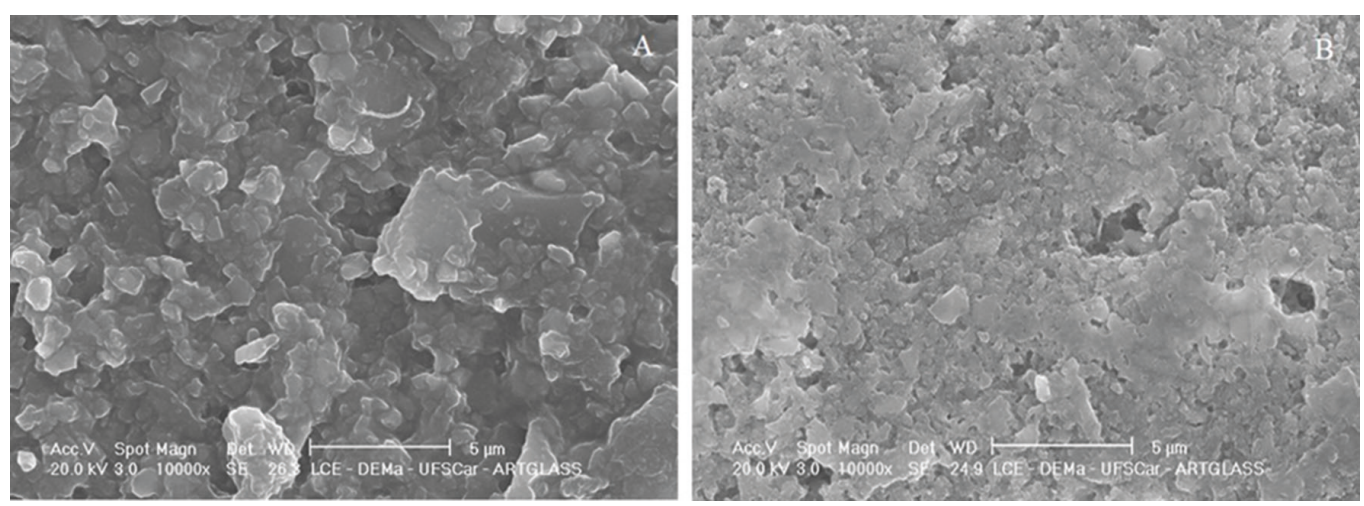

FIGURE 1 | A: Resin Artglass before accelerated artificial aging (AAA). B: Resin Artglass after AAA. 

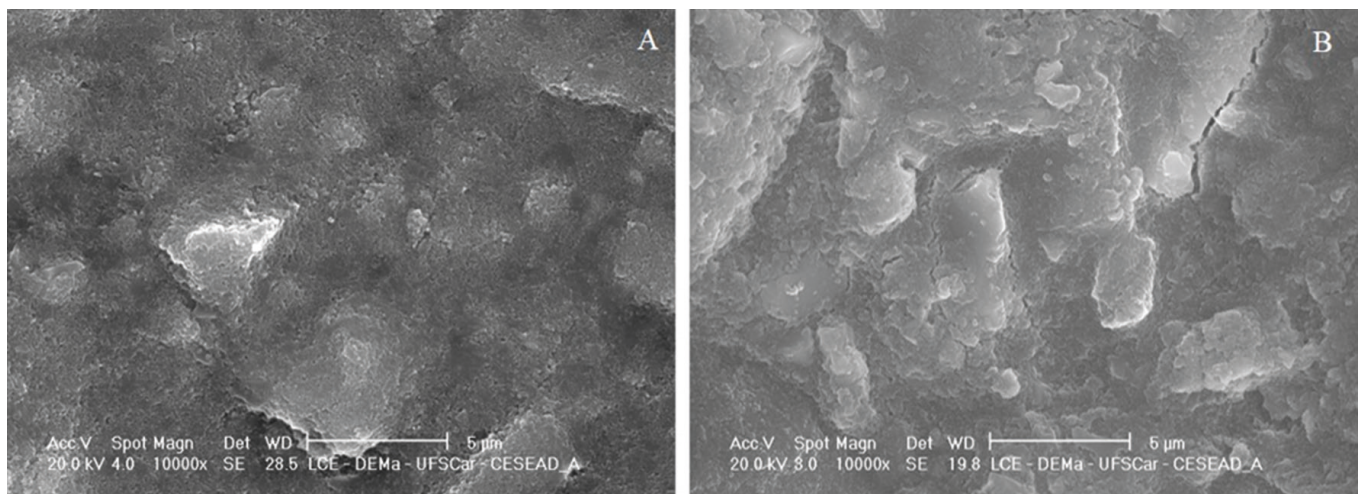

FIGURE 2 || A: Resin Cesead before accelerated artificial aging (AAA). B: Resin Cesead after AAA.
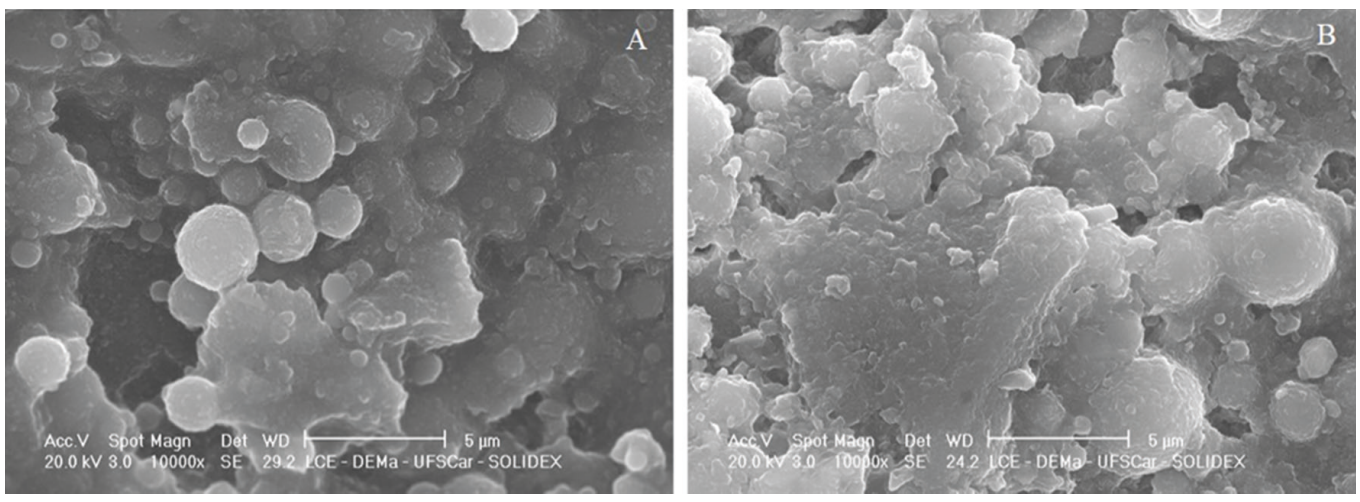

FIGURE 3 || A: Resin Solidex before accelerated artificial aging (AAA). B: Resin Solidex after AAA.

\section{DISCUSSION}

Resin restorations are continuously exposed to coloring and degradation agents due to daily intake of pigmented food and beverages, and adverse conditions in the oral environment. ${ }^{5,6}$ There is no unanimity about the incidence of failures that lead to replacing the composites, however, today the main cause of changing resins, direct or indirect indication, is the change in color. As a result and because of the aesthetic excellence sought by patients, composite manufacturers continuously seek to improve the optical properties of these materials to enable the adequate reproduction of natural teeth characteristics. ${ }^{17,21}$

The size and number of internal particles and differences in the chemical structure of composites can affect light scattering and affect these materials color stability.$^{14,17}$ The breaking of chemical constituents can also change the color of resins in time ${ }^{19,22}$, a situation reproduced in the study through artificial accelerated aging, which simulates the effect of ultraviolet UV-B, responsible for photochemical degradation and moisture, which coupled with other factors can lead to polymer degradation.

The results of this investigation support the rejection of the null hypothesis that there would be no influence of AAA in color stability and surface degradation of different modified composites. Evaluated by the optical luminosity L*, the materials showed variability from the point of view of this factor, in which the Solidex resin demonstrated highest pre stability ( $\left.\mathrm{L}^{*} 76.55 \pm 0.56\right)$ and Cesead the lowest after aging $\left(\mathrm{L}^{*} 76.56 \pm 0.48\right)$. Luminosity 
is an important property for modified indirect composites to meet the necessary aesthetic requirements of a restoration, therefore it is expected of an ideal composite to maintain this characteristic over time.

AAA causes internal discolorations in the resin, therefore the change in color of the composites after UV irradiation has been associated with changes in chemical activators or initiator system, and in the resinous matrix. Therefore, the degradation of the residual amine and the oxidation reaction of carbon double bonds result in the formation of yellowish compounds. ${ }^{12,21}$ In this study, the effect of aging on the Artglass resin did not significantly affect the amount of yellow, unlike other materials, and Cesead and Solidex showed higher $b^{*}$ values after AAA.

The total color change, that is, Delta $\mathrm{E}(\Delta \mathrm{E})$ change is related to changes in the resin matrix, as well as to changes in the matrix/filler set. Indirect resins, micro-hybrids, have a differentiated matrix/filler system to prevent the discoloration of resins, which attributes polyglass or ceromer characteristics to these materials. In this system, AAA promotes a color change in the composites, due to the erosion of the matrix and exposure of the filler particles.

In this study, three different intervals were used to determine color changes: $\Delta E<1-$ imperceptible to the human eye; $1.0<\Delta E<3.3$ - visible only by a skilled and clinically acceptable individual; $\Delta E>3.3$ - easily observed and clinically unacceptable. ${ }^{12,19,20}$ Considering these intervals, only the Cesead resin showed unacceptable color change $(\Delta E=3.51 \pm 1.04)$, the other two, Artglass and Solidex, showed acceptable and similar results.

According to some authors, composites with lower load particle concentrations have higher $\Delta E$ values, contrary to what was observed for the Cesead resin, which had the highest filler amount (82\% silica and quartz glass, and $18 \%$ resin and additives), which showed a higher color change, results that were also previously observed by other authors. ${ }^{17,19}$

In addition to discoloration, other damages were observed in the materials investigated. Scanning electron microscopy images revealed the presence of cracks, especially in the Cesead resin, and deterioration of the organic matrix with the non-adhesion of filler particles, which produces pores and provides higher color change, results that have been also found in other studies. ${ }^{10,12}$ These failures could vary with different filler particles ${ }^{23}$ and may be potentialized in the oral environment due to its greater destructive capacity, which combines physical factors, such as temperature fluctuations and changes in $\mathrm{pH}$, and mechanical interferences, such as shear stress and compression strength. ${ }^{24}$

Although the Solidex resin had the highest color stability and Artglass had clinically acceptable results, it should be noted that all composites analyzed showed color instability when subjected to AAA. Therefore, in light of the limitations of each material, it is up to the dentist and the dental prosthesis technician to use the proper materials according to their indication.

All materials analyzed exhibited color instability and surface degradation, however, only the Cesead resin demonstrated clinically acceptable results.

\section{REFERENCES}

1. Heintze SD, Rousson V, Hickel R. Clinical effectiveness of direct anterior restorations--a meta-analysis. Dent Mater. 2015 May;31(5):481-95. doi: 10.1016/j.dental.2015.01.015.

2. Castro DT, Lepri CP, Valente ML, Reis AC. Mechanical properties of silorane-based and methacrylate-based composite resins after artificial aging. Gen Dent. 2016 MarApr;64(2):56-9.

3. Alvanforoush N, Palamara J, Wong R, Burrow MF. A comparison between published clinical success of direct resin composite restorations in vital posterior teeth in 1995-2005 and 2006-2016 periods. Aust Dent J. 2016 Nov 16. doi:10.1111/ adj.12487. 
4. Ástvaldsdóttir Á, Dagerhamn J, van Dijken JW, Naimi-Akbar A, Sandborgh-Englund G, Tranæus S, et al. Longevity of posterior resin composite restorations in adults - A systematic review. J Dent. 2015 Aug;43(8):934-54. doi: 10.1016/j. jdent.2015.05.001.

5. Ardu S, Duc O, Di Bella E, Krejci I. Color stability of recent composite resins. Odontology. 2017 Jan;105(1):29-35. doi: 10.1007/s10266-016-0234-9.

6. Manojlovic D, Dramićanin MD, Lezaja M, Pongprueksa P, Van Meerbeek B, Miletic V. Effect of resin and photoinitiator on color, translucency and color stability of conventional and low-shrinkage model composites. Dent Mater. 2016 Feb;32(2):183-91. doi: 10.1016/j.dental.2015.11.027.

7. Ferracane JL. Resin composite: state of the art. Dent Mater. 2011 Jan;27(1):29-38. doi: 10.1016/j.dental.2010.10.020.

8. Cramer NB, Stansbury JW, Bowman CN. Recent advances and developments in composite dental restorative materials. J Dent Res. 2011 Apr;90(4):402-16. doi: 10.1177/0022034510381263.

9. Fonseca AS, Gerhardt KM, Pereira GD, Sinhoreti MA, Schneider LF. Do new matrix formulations improve resin composite resistance to degradation processes? Braz Oral Res. 2013 Sep-Oct;27(5):410-6. doi: 10.1590/S180683242013000500005 .

10. Oei JD, Mishriky M, Barghi N, Rawls HR, Cardenas HL, Aguirre R, et al. Development of a low-color, color stable, dual cure dental resin. Dent Mater. 2013 Apr;29(4):405-12. doi: 10.1016/j.dental.2013.01.005.

11. Festuccia MS, Garcia Lda F, Cruvinel DR, Pires-De-Souza Fde C. Color stability, surface roughness and microhardness of composites submitted to mouthrinsing action. J Appl Oral Sci. 2012 Mar-Apr;20(2):200-5.

12. Catelan A, Suzuki TY, Becker F Jr, Briso AL, Santos PH. Influence of surface sealing on color stability and roughness of composite submitted to ultraviolet-accelerated aging. J Investig Clin Dent. 2016 Jan 8. doi: 10.1111/jicd.12203.

13. Salgado VE, Cavalcante LM, Silikas N, Schneider LF. The influence of nanoscale inorganic content over optical and surface properties of model composites. J Dent. 2013 Nov;41 Suppl 5:e45-53. doi: 10.1016/j.jdent.2013.05.011.

14. Mikhail SS, Schricker SR, Azer SS, Brantley WA, Johnston WM. Optical characteristics of contemporary dental composite resin materials. J Dent. 2013 Sep;41(9):771-8. doi: 10.1016/j.jdent.2013.07.001.

15. Tornavoi DC, Agnelli JA, Panzeri H, Dos Reis AC. Color change of composite resins subjected to accelerated artifi- cial aging. Indian J Dent Res. 2013 Sep-Oct;24(5):605-9. doi: 10.4103/0970-9290.123390.

16. ASTM G154-06, Standard practice for operating fluorescent light apparatus for UV exposure of nonmettalic materials. West Conshohocken, PA: ASTM International; 2006.

17. Pinto GC, Dias KC, Cruvinel DR, Garcia LF, Consani S, Pires-De-Souza FC. Influence of finishing/polishing on color stability and surface roughness of composites submitted to accelerated artificial aging. Indian J Dent Res. 2013 MayJun;24(3):363-8. doi: 10.4103/0970-9290.118010.

18. Oliveira DC, Ayres AP, Rocha MG, Giannini M, Puppin Rontani RM, Ferracane JL, et al. Effect of different in vitro aging methods on color stability of a dental resin-based composite using CIELAB and CIEDE20oo color-difference formulas. J Esthet Restor Dent. 2015 Sep-Oct;27(5):322-30. doi: 10.1111/ jerd.12155.

19. Özdaş DÖ, Kazak M, Çilingir A, Subaşı MG, Tiryaki M, Günal Ş. Color stability of composites after short-term oral simulation: an in vitro study. Open Dent J. 2016 Aug 31;10:431-437. eCollection 2016.

20. Moon JD, Seon EM, Son SA, Jung KH, Kwon YH, Park JK. Effect of immersion into solutions at various $\mathrm{pH}$ on the color stability of composite resins with different shades. Restor Dent Endod. 2015 Nov;40(4):270-6. doi: 10.5395/ rde.2015.40.4.270.

21. Uchimura JY, Sato F, Bianchi G, Baesso ML, Santana RG, Pascotto RC. Color stability over time of three resin-based restorative materials stored dry and in artificial saliva. J Esthet Restor Dent. 2014 Jul-Aug;26(4):279-87. doi: 10.1111/ jerd.12106.

22. Ren YF, Feng L, Serban D, Malmstrom HS. Effects of common beverage colorants on color stability of dental composite resins: the utility of a thermocycling stain challenge model in vitro. J Dent. 2012 Jul;40 Suppl 1:e48-56. doi: 10.1016/j. jdent.2012.04.017.

23. Tamura Y, Kakuta K, Ogura H. Wear and mechanical properties of composite resins consisting of different filler particles. Odontology. 2013 Jul;101(2):156-69. doi: 10.1007/s10266012-0074-1.

24. Correr GM, Bruschi Alonso RC, Baratto-Filho F, Correr-Sobrinho L, Sinhoreti MA, Puppin-Rontani RM. In vitro longterm degradation of aesthetic restorative materials in foodsimulating media. Acta Odontol Scand. 2012 Mar;70(2):101-8. doi: 10.3109/00016357.2011.600701. 